\title{
DEEP TIME ORIGINS OF SINKHOLE COLLAPSE FAILURES IN SEWAGE LAGOONS IN SOUTHEAST MINNESOTA
}

\author{
E. Calvin Alexander, Jr. \\ Earth Sciences, University of Minnesota, 310 Pillsbury Dr. SE, Minneapolis, MN 55455, USA, alexa001@umn.edu
}

\author{
Anthony C. Runkel, Robert G. Tipping \\ Minnesota Geological Survey, 2642 University Ave., St. Paul, MN 55114, USA, runke001@umn.edu, \\ tippi001@umn.edu
}

\author{
Jeffrey A. Green \\ MnDNR Ecological \& Water Resources, $35559^{\text {th }}$ St. NW, Suite 350, Rochester, MN 55901, USA, \\ jeff.green@state.mn.us
}

\begin{abstract}
Three of the approximately twenty-three municipal wastewater treatment lagoons constructed in the 1970s and 1980s in southeastern Minnesota's karst region have failed through sinkhole collapse. Those collapses occurred between 1974 and 1992. All three failures occurred at almost exactly the same stratigraphic position. That stratigraphic interval, just above the unconformable contact between the Shakopee and Oneota Formations of the Ordovician Prairie du Chien Group is now recognized as one of the most ubiquitous, regional-scale, karst hydraulic high-transmissivity zones in the Paleozoic hydrostratigraphy of southeastern Minnesota.
\end{abstract}

These karst aquifers have been developing multi-porosity conduit flow systems since the initial deposition of the carbonates about 480 million years ago. The existence of syndepositional interstratal karst unconformities between the Oneota and Shakopee Formations and between the Shakopee and St. Peter Formations, were recognized in the 1800s. About 270 million years ago galena, sphalerite and iron sulfides were deposited in pre-existing solution enlarged joints, bedding planes and caves. The region has been above sea level since the Cretaceous and huge volumes of fresh water have flowed through these rocks. The regional flow systems have changed from east-towest in the Cenozoic, to north-to-south in or before the Pleistocene. The incision of the Mississippi River and its tributaries has and is profoundly rearranging the ground water flow systems as it varies the regional base levels during glacial cycles. The Pleistocene glacial cycles have removed many of the surficial karst features and buried even more of them under glacial sediments. High erosion rates from row crop agriculture between the 1850s and 1930s filled many of the conduit systems with soil. Over eighty years of soil conservation efforts have significantly reduced the flux of mobilized soil into the conduits. Those conduits are currently flushing much of those stored soils out of their spring outlets. Finally, the increased frequency and intensity of major storm events is reactivating conduit segments that have been clogged and inactive for millions of years.

The karst solution voids into which the lagoons collapsed have formed over 480 million years. The recognition and mapping of this major karst zone will allow much more accurate karst hazard maps to be constructed and used in sustainable resource management decisions.

\section{Introduction}

Three of the approximately twenty-three municipal wastewater treatment facility (WWTF) lagoons constructed in the 1970s and 1980s in southeastern Minnesota's karst region have catastrophically failed through sinkhole collapse (Alexander and Book, 1984; Jannik et al., 1992; Alexander et al., 1993). These lagoons are non-mechanical systems that rely on sunlight, air and microbes to treat the wastewater. The first lagoon to fail, the Altura WWTF lagoon, collapsed twice. All four collapses occurred in the same stratigraphic position. That stratigraphic interval is centered on the unconformable contact between the Shakopee and Oneota Formations of the Ordovician Prairie du Chien Group (Mossler, 2008). That interval is a regional-scale, karst hydraulic hightransmissivity zone in the Paleozoic hydrostratigraphy of southeastern Minnesota (Runkel et al., 2003; Tipping et al., 2006). The interval has long been known as a productive zone by the water well drilling community. 
The sinkhole collapses were induced by the lagoons' construction and operation. Were these collapses random, unpredictable "acts of God"? Or did the collapses result from the interactions between deep time geology with recent human activities? Can we improve the safety of future analogous facilities? Can we evaluate/prioritize the future collapse risk of the regions' remaining WWTF lagoons? These questions are the focus of this paper.

\section{Hydrogeologic Setting}

Mossler (2008) and references listed therein are the basis for much of this section. To construct the current lithostratigraphic nomenclature of Minnesota's Lower and Middle Paleozoic sedimentary rocks, Mossler definitively reviewed the region's structural and sedimentological framework.

Most of Minnesota's karst features and important bedrock karst aquifers occur in southeastern (SE) Minnesotathe area roughly south and east of the Twin Cities Metropolitan area. SE Minnesota forms the east limb of the gently southward dipping Hollandale Embayment. The regional dip is about two meters per kilometer to the southwest but local structures with several meters of amplitude are hydrogeologically important.

Figure 1 shows the structural context of the Middle and Lower Paleozoic rocks in the upper Mississippi River Valley (UMV). The adjacent areas in southwestern Wisconsin, northwestern Illinois and northeastern Iowa, with southeastern Minnesota, comprise the UMV Karst.

The Paleozoic sedimentary units are relatively thin, regionally extensive, siliciclastic and carbonate rocks that can be correlated across the UMV Karst. These rocks were deposited during three episodes of complex sea transgressions during the Paleozoic. The tops of each episode are characterized by interregional unconformities. Because SE Minnesota was near the center of the craton, it was among the last places to be flooded during transgression and the first to be exposed to erosion as the sea withdrew. The tops and bottoms of many of the units are marked by erosional unconformities.

Conventional geologic columns show the sequence of rocks exposed as the rocks appear in outcrop or drill core. The columns diagram the rock types and linear thicknesses. The geologic ages of the rocks are indicated in a non-linear fashion. Erosional unconformities can

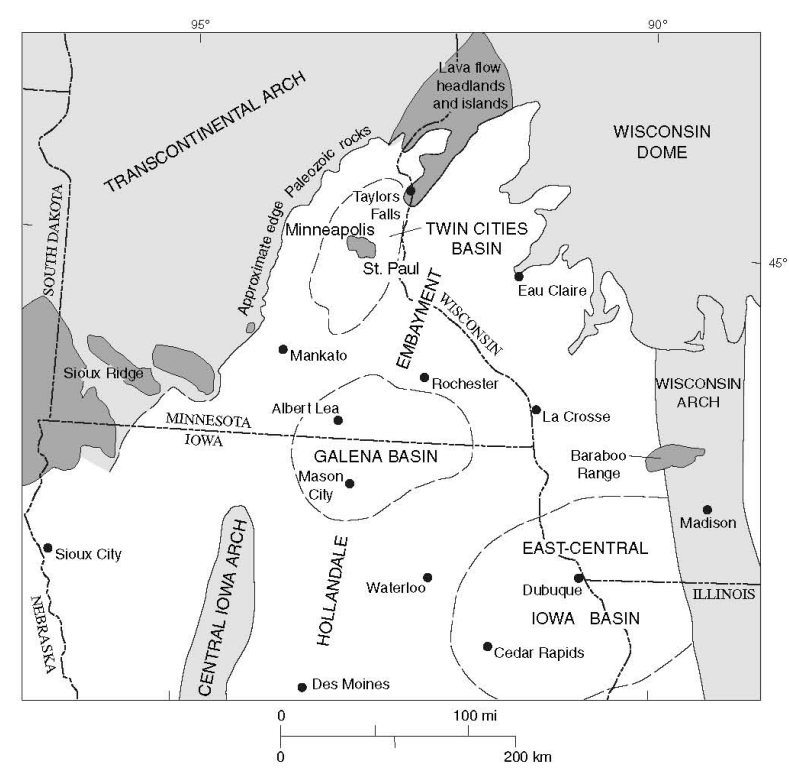

Figure 1. Regional geologic setting of the Lower and Middle Paleozoic rocks in SE Minnesota (Mossler, 2008, Figure 2B).

be seen but are inconspicuous. Figure 2 is a simplified geologic column from SE Minnesota modified from Mossler (1987, 2008). This column nicely demonstrates that siliciclastic sandstones, mudstones and shales dominate in the upper Cambrian column of SE Minnesota, that carbonates dominate in the Ordovician section and that the two fundamentally different rock types are inter-fingered.

A conventional geologic column is one of the most basic conceptual tools used by hydrogeologists and geoengineers to understand and describe the region. Geologic columns are a fundamental tool to present geologic concepts to the public. From a karst perspective, however, they have an important failing. They significantly underemphasize the number, magnitude and importance of unconformities formed by erosion. It was during these erosion periods that karst features could and did develop. The unconformities have been emphasized with bold black lines in Figure 2.

Figure 3 is Mossler's (2008) SE Minnesota Geologic column displaying the same information on a linear time scale. This geologic column emphasizes the relatively rapid deposition of the lower siliciclastic-dominated rocks. The Upper Cambrian Mt. Simon through the Jordan, i.e. roughly $250 \mathrm{~m}(820 \mathrm{ft})$ of siliciclastic rocks, were deposited in about 10 million years. The remaining about $100 \mathrm{~m}$ (330 ft) of the Lower Ordovician Prairie 


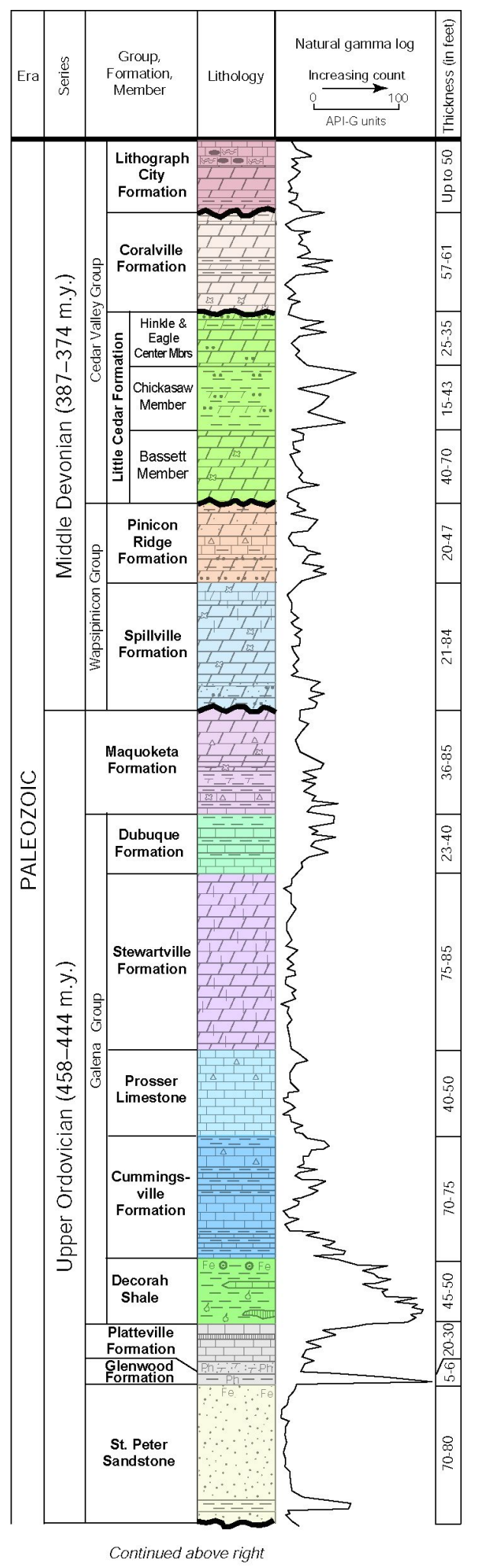

Figure 2. Lithostratigraphic column for the Lower and Middle Paleozoic rocks in southeast Minnesota. The bold black, wavy lines emphasize the unconformities. Modified from (Mossler 1987, 2008).

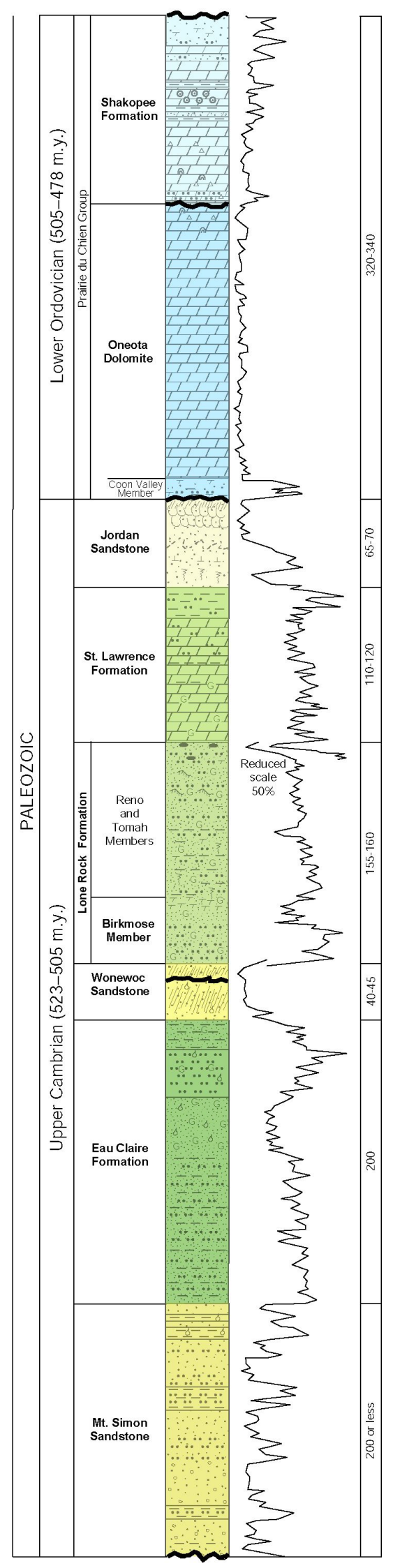



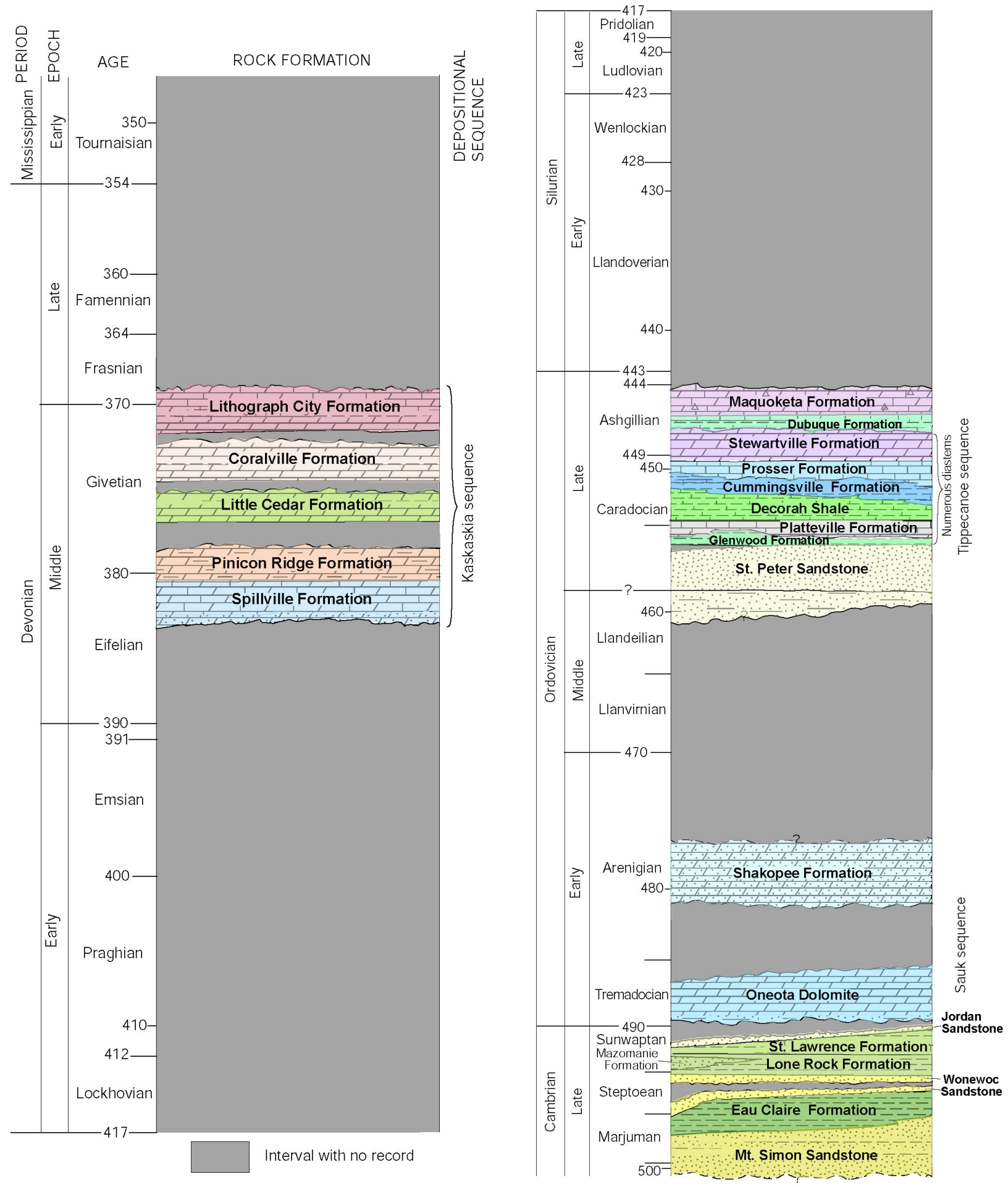

Figure 3. Chronostratigraphic column for Lower to Middle Paleozoic rocks in southeast Minnesota. Modified from (Mossler, 2008, Figure 1). 
du Chien carbonates were deposited in two roughly 5 million year episodes with a 5 million year gap between.

An unconformity representing a gap of over 15 million years separates the Prairie du Chien from the Upper Ordovician St. Peter through Maquoketa sequence, which was deposited in about 10 million years. The Devonian Spillville through Lithograph City carbonates represent about 15 million years of time, including three significant unconformity gaps. The remaining 135 million years of the Cambrian through Devonian time left no depositional record in SE Minnesota. During those enormous unconformity time gaps the lower Paleozoic carbonates were infiltrated by fresh surface waters and subject to karst solution.

\section{Karst Processes in SE Minnesota and the mid Prairie du Chien karst high-transmissivity zone}

\section{Paleozoic karst processes}

Hedges and Alexander's (1985) review of karst features in the UMV region gathered references to "paleokarsts of Ordovician, Devonian, Pennsylvanian and Cretaceous ages" and "interstratal karstification between the Shakopee dolomite and the overlying St. Peter sandstone, between the Oneota dolomite and the overlying New Richmond sandstone and between the Oneota dolomite and the underlying Blue Earth siltstone." Geologic references to paleokarst features in the UMV date back at least to Barris (1880) and Farnsworth (1888). Farnsworth (1888) refers to an 1854 Iowa Geological Survey report of clay filled caves and fissures in Devonian limestones (Hall and Whitney, 1858).

Karstification of the top of the Oneota Formation during the 4 to 5 million year subaerial erosional unconformity before the deposition of the Shakopee Formation and subsequent regional groundwater flow systems, extending to the present day, have produced arguably the most significant, best developed and mappable hightransmissivity zone in the Paleozoic hydrogeology of SE Minnesota.

Runkel et al. (2003) and Tipping et al., (2006) have documented the hydrogeologic importance of this feature. Figure 4 diagrams the position and extent of this feature in southeastern Minnesota.
The mid-Prairie du Chien karst high-transmissivity zone is a very old feature. It started as solution weathering and karstification of the top of the Oneota during the 4 to 5 million year unconformity between the Oneota and the overlying Shakopee. The geometry of the overlying Shakopee, itself highly karstified beneath the sub-St. Peter large magnitude unconformity, insured that the stratigraphic interval would localize what is a regional scale flow system.

Smith (1997) documented that solution removal of anhydrite and the subsequent brecciation of the eroding top of the Oneota played an important role in developing the karst high-transmissivity zone, during the subaerial weathering before the deposition of the Shakopee. Smith et al. (1997) further emphasize that authigenic silica fabrics present in this unconformity document that silicification occurred before and during the erosional unconformity, i.e., that karstification was syndepositional.

About 270 million years ago galena, sphalerite and iron sulfides were deposited in pre-existing solutionally enlarged joints, bedding planes and caves in the UMV. This includes precipitation of these mineral into macropores associated with the paleokarsts feature in the upper Oneota dolomite (Runkel et al., 1993).

\section{Karst processes from the Mesozoic to present}

The UMV region has been above sea level since the Mesozoic and huge volumes of fresh water have flowed through these rocks. The regional flow systems have changed from east-to-west in the Mesozoic and Cenozoic, to north-to-south in or before the Pleistocene. The climate was warm to tropical during much of this period and karst process must have been an important component of the ongoing surficial processes. The incision of the Mississippi River and its tributaries has and is profoundly rearranging the ground water flow systems as it changes the regional base level during glacial cycles.

The Pleistocene glacial cycles removed much of the preexisting epikarst and many surficial karst features. Large areas of karstified carbonate bedrock were buried under 50 to 150 meters of glacial sediments with the internal karst features intact. High soil erosion rates from row crop agriculture between the 1850s and 1930s filled 


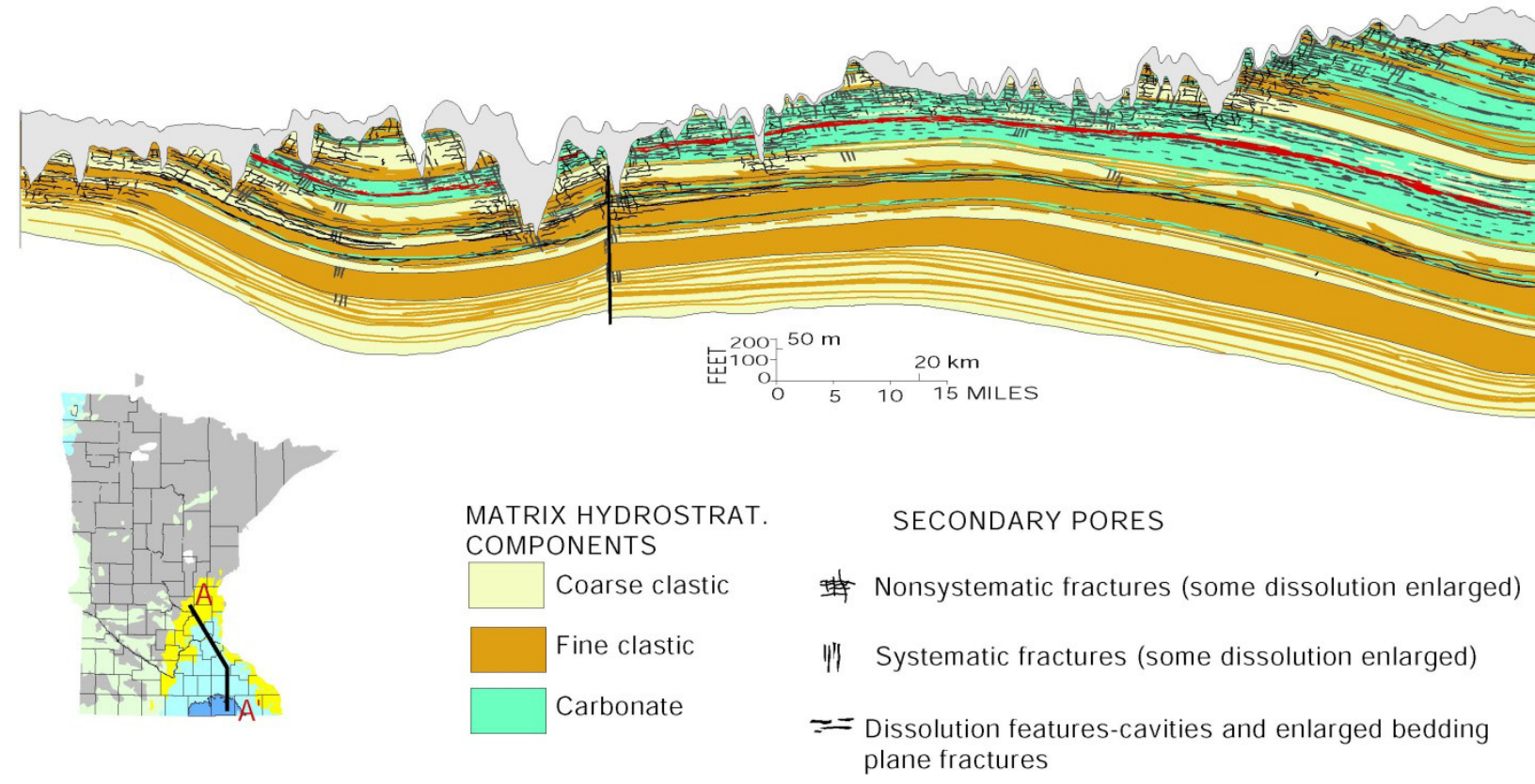

Figure 4. Southeast Minnesota hydrostatigraphic cross section, schematically showing solutionally-enhanced fractures and voids (not to scale). The karst high-transmissivity zone near the middle of the Lower Ordovician Prairie du Chien Group is highlighted in red.

many of the conduit systems with soil. Soil conservation efforts that began in the 1930s have significantly reduced the amount of soil moving into the conduits. Precipitation events are now flushing stored sediment out of the conduits.

The increased frequency and intensity of major storm events over the past few decades may be reactivating portions of conduit segments that have been clogged and inactive for millions of years. There may be many currently inactive conduits (plugged by ancient, glacial and modern sediments) that are being reactivated as hydrologic conditions change and the plugs are flushed out.

The contact zone between the Prairie du Chien and the Shakopee has long been known as a productive zone by the local water well drillers. This cavernous zone is easily recognized in hydrophysical logging of area water wells.

Dalgleish and Alexander (1984, Figure 7, p. 83) documented the dominance of this stratigraphic interval on the distribution of sinkholes in Winona County, where three of the four collapses occurred. In Wabasha County, which contains the fourth collapse site, sinkholes are more likely to occur where this stratigraphic interval coincides with the water table position (Tipping et al., 2001). Finally, that the four sinkhole collapses in WWTF lagoons were constructed where this zone is the uppermost bedrock (Alexander and Book, 1984; Jannik et al., 1992; Alexander et al., 1993) further emphasizes the geoengineering and environmental management importance of this zone in SE Minnesota.

\section{Conclusion}

The collapse of the Altura, Lewiston and Bellchester, Minnesota, WWTF lagoons were not random, unpredictable events. The collapses occurred as a result of siting the lagoons immediately on top of the midPrairie du Chien high-transmissive zone - the largest, most developed regional karst solution zone in SE Minnesota.

\section{The opportunity and the challenge}

When these WWTF lagoons were designed and built in the 1970s and 1980s, the current understanding of the hydrogeologic and environmental importance of the mid-Prairie du Chien karst high-transmissivity zone did not exist. The basic geologic information existed but had not been assimilated into the hydrogeologic or geoengineering communities who designed and built the 
lagoons. That technical information had also not been transmitted to regulatory officials. No one recognized that a problem existed, much less how to prevent it.

We now have the tools and knowledge to incorporate more focused, nuanced karst hydrogeology and geoengineering concepts and practices into evaluating and managing the operation of in-place infrastructure and practices. We can upgrade the design and operation of new infrastructure and practices.

The use of karst hydrogeologic and geoengineering concepts to collect, interpret and apply new tools to gather much larger quantities of higher quality, more detailed data and information to infrastructure siting and management issues is very promising. One example is the use of modern Geographic Information System tools, accurate Global Positioning Satellite technology, LiDAR DEMs and surface feature maps, growing data bases of local subsurface information from well drillers and other sources, and a variety of geophysical tools. Such tools significantly enhance the precision and accuracy of more traditional bedrock, structural and karst mapping techniques. We have the ability to create accurate, specialized subcrop area maps of the mid- Prairie du Chien karst high-transmissive zone. Such maps will allow the existing infrastructure to be prioritized according to relative sinkhole failure probability, and to guide siting decisions for future infrastructure. These maps can also be used to influence resource management decisions.

\section{Acknowledgments}

Funding for this project was provided by the Minnesota Environment and Natural Resources Trust Fund as recommended by the Legislative-Citizen Commission on Minnesota Resources (LCCMR).

\section{References}

Alexander EC Jr, Book PR. 1984. Altura Minnesota lagoon collapses. In: Beck B, editor. Sinkholes: Their Geology, Engineering and Environmental Impact, Proceedings of the First Multidisciplinary on Sinkholes; $15-17$ Oct 1984; Orlando (FL): A.A. Balkema. p. 311-318.

Alexander EC Jr, Broberg JS, Kehren AR, Graziani MM, Turri WL. 1993. Bellechester Minnesota lagoon collapses. In: Beck BF, editor. Applied Karst Geology, Proceedings of the Fourth Multidisciplinary Conference on Sinkholes and the Engineering and Environmental Impacts of Karst; 25-26 Jan 1993; Panama City Beach (FL): A.A. Balkema. p. 63-72.
Barris WH. 1880. The Local Geology of Davenport and Vicinity. Proceedings of the Davenport Academy of Natural Science 2: 261-269.

Dalgleish JD, Alexander EC Jr. 1984. Sinkhole distribution in Winona County, Minnesota. . In: Beck B, editor. Sinkholes: Their Geology, Engineering and Environmental Impact, Proceedings of the First Multidisciplinary on Sinkholes; 15-17 Oct 1984; Orlando (FL): A.A. Balkema. p. 79-85.

Farnsworth PJ, 1888. Pockets Containing Fire-Clay and Carbonaceous Material in the Niagara Limestone at Clinton, Iowa. American Geologist 2-5: 331-334.

Hall J, Whitney JD. 1858. Geological Survey of the State of Iowa: Embracing the Results of Investigations Made During Portions of the Years 1855, 56 \& 57. Vol. I, Part 1: Geology, p. 129-131, Fig. 9-10.

Hedges J, Alexander EC Jr. 1985. Karst-related features of the Upper Mississippi Valley Region. Studies in Speleology 6: 41-49.

Jannik NO, Alexander EC Jr, Landherr LJ. 1992. The sinkhole collapse of the Lewiston, MN waste water treatment facility lagoon. In: Quinlan J, Stanley A, editors. Proceedings of the Third Conference on Hydrogeology, Ecology, Monitoring of Ground Water in Karst Terranes; 4-6 Dec 1992; Nashville (TN): National Ground Water Association. p. 715-724.

Mossler JH. 1987. Paleozoic Lithostratigraphic Nomenclature for Minnesota. Minnesota Geological Survey Report of Investigations 36; St. Paul (MN): $32 \mathrm{p}$.

Mossler JH. 2008. Paleozoic Lithostratigraphic Nomenclature for Minnesota. Minnesota Geological Survey Report of Investigations 65; St. Paul (MN): 83 p.

Runkel AC, Morey GB, Lively RS, Mossler JH, Ingebritson, RH. 1993. Outlying Mississippi Valley-type sulfide mineralization, Fillmore County, Minnesota. In: Shelton KL, Hagni RD, editors. Geology and Geochemistry of Mississippi Valley-Type Ore Deposits, Proceedings. University of Missouri at Rolla. p. 187-193.

Runkel AC, Tipping RG, Alexander EC Jr, Green JA. 2003. Hydrogeology of the Paleozoic Bedrock in Southeastern Minnesota. Geological Survey, Report of Investigations 61; St. Paul (MN): 113 p.

Smith GL. 1997. Complex brecciation history associated with evaporite and carbonate dissolution in the Lower Ordovician Oneota Formation (Prairie Du Chien Group) near Spring Green, Wisconsin. Geosciences Wisconsin 16: 17-23. 
Smith GL, Dott RH Jr, Byers CW. 1997. Authigenic silica fabrics associated with Cambro-Ordovician unconformities in the Upper Midwest. Geosciences Wisconsin 16: 25-36.

Tipping RG, Green J, Alexander EC Jr. 2001. Karst Features. In: Runkel AC, project manager. Geologic Atlas of Wabasha County, Minnesota: County Atlas Series C-14, Part A. Minnesota Geological Survey, St. Paul (MN): plate 5 .

Tipping RG, Runkel AC, Alexander EC Jr, Alexander SC. 2006. Hydrostratigraphic characterization of intergranular and secondary porosity in part of the Cambrian Sandstone aquifer system of the cratonic interior of North America: Improving predictability of hydrogeologic properties. Sedimentary Geology 184: 305-330. 